\title{
DETERMINAN KINERJA GURU SMK BIDANG KEAHLIAN TEKNIK MESIN
}

\author{
Wagiran, Soenarto, FX Soedarsono \\ Universitas Negeri Yogyakarta \\ Jl. Colombo, Karang Malang, Yogyakarta 55281 \\ maswagiran@yahoo.com, soenarto@uny.ac.id,
}

\begin{abstract}
Abstrak
Penelitian ini bertujuan untuk (1) mengetahui gambaran faktor situasional, faktor psikologis, dan kinerja guru SMK di Daerah Istimewa Yogyakarta; (2) menemukan pengaruh faktor situasional dan faktor psikologis terhadap kinerja guru SMK di Daerah Istimewa Yogyakarta; (3) merumuskan hubungan kausal kepemimpinan kepala sekolah, budaya sekolah, imbalan, kemampuan guru, komitmen guru, motivasi kerja guru terhadap kinerja guru SMK di Daerah Istimewa Yogyakarta. Penelitian yang dilakukan merupakan penelitian korelasional dan bersifat ex-post facto. Sampel sejumlah 155 ditentukan dengan Formula Cohen dengan teknik proportionale random sampling. Data dikumpulkan dengan inventori, lembar pengamatan, dan self assessment. Validasi isi dilakukan dengan expert judgment. Validasi konstruk dilakukan dengan analisis faktor dan reliabilitas ditentukan dengan rumus Alpha Cronbach. Data dianalisis dengan analisis deskriptif, analisis regresi dan analisis jalur. Interpretasi hasil analisis data menggunakan taraf signifikansi 0,05. Hasil analisis deskriptif menunjukkan bahwa kepemimpinan kepala sekolah, budaya sekolah, imbalan, kemampuan guru, komitmen guru, motivasi kerja guru, dan kinerja guru termasuk dalam kategori tinggi.
\end{abstract}

Kata kunci: kinerja guru, Sekolah Menengah Kejuruan, faktor psikologis, faktor situasional 


\title{
DETERMINANT OF SMK TEACHERS' PERFORMANCE IN THE FIELD OF MECHANICAL ENGINEERING EXPERTISE
}

\author{
Wagiran, Soenarto, FX Soedarsono \\ Universitas Negeri Yogyakarta \\ Jl. Colombo, Karang Malang, Yogyakarta 55281 \\ maswagiran@yahoo.com, soenarto@uny.ac.id
}

\begin{abstract}
This study was aimed at: (1) describing the situational factors, psychological factors, and vocational high school teachers' performance; and (2) revealing determination of situational factors (principal's leadership, school culture, and compensation), and psychological factors (teachers' ability, teachers' commitment, teacher's work motivation) to vocational high school teachers' performance, (3) revealing causal effect of principal's leadership, school culture, compensation, teachers' ability, teachers' commitment, and teacher's work motivation to vocational high school teachers' performance. This ex-post facto research was done at mechanical engineering program in technological and industrial vocational high schools at Yogyakarta Special District. The population was 187 teachers and samples of 155 teachers were determined using the Cohen formula and proportional random sampling technique. Data were collected through inventory, observations, and self assessment. Analysis of content validity was conducted by expert judgment and construct validity was conducted using factors analysis. Reliability analysis was conducted using Cronbach Alpha formula. The data were analyzed using descriptive methods, correlations, regression, and path analysis. The result of descriptive analysis showed that principal's leadership, school culture, compensation, teachers' ability, teachers' commitment, teachers' work motivation, and vocational high school teachers' performance was in high category.
\end{abstract}

Keywords: teachers' performance, vocational high school, psychological factors, situational factors 


\section{Pendahuluan}

Berbagai upaya telah dilakukan oleh lembaga pendidikan menengah kejuruan dalam hal ini SMK, agar menghasilkan lulusan yang benar-benar dibutuhkan oleh dunia kerja sebagai wujud pertanggungjawabannya kepada masyarakat. Upaya tersebut di antaranya adalah kebijakan link and match, pendidikan sistem ganda, pendidikan berbasis kompetensi, broad-based education, life skill education, manajemen berbasis sekolah, hingga penerapan kurikulum tingkat satuan pendidikan (KTSP) yang kesemuanya bertujuan meningkatkan kualitas lulusan sesuai dengan kebutuhan nyata di lapangan kerja.

Salah satu faktor mendasar yang menentukan ketercapaian tujuan pendidikan kejuruan adalah guru. Peran guru amat signifikan bagi setiap keberhasilan proses pembelajaran (Jones, Jenkin \& Lord, 2006:1). Dari begitu banyak variabel yang menentukan pendidikan, muncul bukti-bukti bahwa kemampuan guru merupakan variabel terpenting atas kualitas hasil pembelajaran (Zamroni, 2008:40). Ungkapan menyatakan "kalau ingin melihat prestasi siswa lihatlah kualitas gurunya" (Zamroni, 2009: 4). Guru dituntut mampu memfasilitasi proses pembelajaran aktif yang mampu membangkitkan minat dan kemauan siswa dalam mengoptimalkan potensi yang dimiliki. Dalam konteks ini menjadi penting bagi seorang guru untuk memiliki kompetensi dan bertindak efektif sebagai salah satu kunci keberhasilan pembelajaran. Studi di negara-negara berkembang menunjukkan bahwa faktor guru memberikan sumbangan dalam prestasi belajar siswa sebesar $36 \%$, diikuti dengan faktor manajemen sebesar $23 \%$, faktor waktu belajar sebesar 22\%, dan faktor sarana fisik sebesar 19\% (Sidhi, 2000).

Mengingat pentingnya peran guru dalam menentukan kualitas pendidikan termasuk pendidikan kejuruan, berbagai upaya telah dilakukan dalam rangka meningkatkan kualitas guru baik melalui pendidikan, pelatihan, pemagangan maupun program lain termasuk sertifikasi. Namun demikian data di lapangan menunjukkan masih banyaknya permasalahan yang dihadapi dalam upaya meningkatkan kualitas dan kinerja guru pendidikan kejuruan. 
Data pada tahun 2006 menunjukkan bahwa hampir separuh dari lebih kurang 2,6 juta guru di Indonesia tidak memiliki kompetensi layak untuk mengajar. Guru yang tidak layak mengajar berjumlah 912.505, terdiri dari 605.217 guru SD, 167.643 guru SMP, 75.684 guru SMA, dan 63.962 guru SMK. Selain itu tercatat 15 persen guru mengajar tidak sesuai dengan keahlian yang dimiliki atau bidangnya (Kompas, 5/1/2006). Jika mengacu pada syarat yang ditetapkan Undang-Undang Nomor 14 Tahun 2005 tentang Guru dan Dosen, bahwa guru yang berkualitas harus berkualifikasi pendidikan D-IV/S-1, maka terdapat 1,7 juta guru di Indonesia masih berpendidikan SMA-D-III. Kesejahteraan guru juga memprihatinkan. Masih banyak guru yang digaji Rp50.000,00-Rp100.000,00 perbulan. Adanya status kerja guru honor daerah dan guru honor sekolah menyebabkan posisi guru lemah dan sewaktu-waktu bisa dipecat tanpa menerima haknya (Kompas 4 Oktober 2008).

Data dari SIM PTK Ditjen PMPTK (Zamroni, 2007:7) menyebutkan bahwa dari sisi kuantitas jumlah guru SMK saat ini sebesar 158.486 orang atau 7,4\% dari jumlah guru di Indonesia sebesar 2.139.951. Dilihat dari kualifikasi pendidikannya baru sebesar $76,28 \%$ guru SMK layak mengajar, atau masih terdapat $23,72 \%$ guru tidak layak mengajar. Hal ini selaras dengan temuan Baedlowi (2009) yang mengungkapkan bahwa dari sejumlah 2.607.311 guru di Indonesia, baru sejumlah 1.043.000 guru (40\%) yang memiliki pendidikan diploma empat atau S1. Dengan demikian masih terdapat 1.564.311 guru atau 60\% guru yang belum memenuhi kelayakan mengajar dilihat dari tingkat pendidikan. Data terbaru menurut Menteri Pendidikan Nasional (Kedaulatan Rakyat, 17 Mei 2010) menunjukkan bahwa masih terdapat 54\% guru yang tidak memenuhi kualifikasi. Permasalahan ini masih ditambah dengan banyaknya guru yang mengajar di luar bidang keahliannya. Kecenderungan kurangnya wawasan profesional guru, ketidaksesuaian latarbelakang pendidikan dengan mata pelajaran yang diajarkan, dan motivasi kerja guru yang kurang optimal dapat menyebabkan kinerja guru rendah.

Nurlaela (2008:847-854) dalam penelitian deskriptif tentang kinerja guru setelah sertifikasi menyimpukan bahwa (1) pada unsur kualifikasi dan tugas pokok, sebagian besar guru telah melaksanakan beban kerjanya sesuai 
dengan ketentuan (24 jam/minggu), namun hal-hal yang terkait dengan pembuatan perencanaan pembelajaran, pelaksanaan pembelajaran yang berpusat pada siswa, dan penerapan penilaian alternatif, masih harus terus ditingkatkan; (2) pada unsur pengembangan profesi, sebagian besar guru masih tetap mengikuti diklat peningkatan kompetensi, namun dalam hal penulisan karya tulis dan penelitian masih memprihatinkan; dan (3) pada unsur pendukung profesi, kebanyakan guru jarang mengikuti forum ilmiah. Hasil penelitian ini menunjukkan bahwa pada dasarnya kinerja guru baik sebelum maupun setelah sertifikasi masih rendah dan perlu men-dapatkan perhatian serius.

Peraturan Pemerintah No.16 Tahun 2007 tentang Standar Kualifikasi Akademik dan Kompetensi Guru tertanggal 4 Mei 2007 menyebutkan bahwa standar kompetensi guru dikembangkan secara utuh dari empat kompetensi utama, yaitu kompetensi pedagogik, kompetensi kepribadian, kompetensi sosial dan kompetensi profesional yang terintegrasi dalam kinerja guru. Dalam konteks tersebut, penilaian atas kinerja guru merupakan penjumlahan kumulatif semua unsur kompetensi sebagai satu kesatuan yang utuh.

Gambaran kinerja guru dapat dicermati salah satunya dari hasil sertifikasi guru yang telah dilakukan dua periode yaitu pada tahun 2006 dan 2007. Departemen Pendidikan Nasional (2008b) menginformasikan bahwa sampai dengan September 2008 terdapat 181.443 guru lolos sertifikasi. Angka kelulusan portofolio untuk kuota tahun 2006 adalah sebesar 49,08\% (9.815 dari 20.000 guru), sedangkan untuk kuota tahun 2007 adalah sebesar 41,17\% (74.289 dari 180.450 guru). Berdasarkan angka tersebut tampak bahwa kinerja guru termasuk guru SMK dinilai dari aspek portofolio kinerjanya masih tergolong rendah. Rendahnya tingkat kelulusan tersebut masih ditambah dengan tidak meratanya kualitas guru yang dapat dicermati dari hasil penilaian portofolio dari 13 rayon di seluruh Indonesia (bttp:// sertifikasiguru.org/index.php?page=2007-2). Data tersebut menunjukkan bahwa tingkat kelulusan antardaerah rata-rata masih rendah dan bervariasi. Adanya temuan-temuan kecurangan dalam pengumpulan portofolio guru menjadikan permasalahan lebih kompleks (bttp://sertifikasiguru.org/index.php 
?mact). Hal ini menunjukkan masih diperlukannya upaya keras dalam meningkatkan kinerja guru.

Apabila kinerja dikaitkan dengan beban mengajar minimal 24 jam sesuai amanat Pasal 35 Ayat 2 Undang-undang Nomor 14 tahun 2005 tentang Guru dan Dosen, terlihat bahwa sebagian besar guru sulit untuk memenuhinya, terlebih lagi untuk guru swasta. Guru-guru di sekolah swasta di sekolah kecil umumnya mengajar 12-18 jam per minggu. Dalam kaitan sertifikasi, guru-guru terpaksa mengajar dua bidang studi atau mengajar di sekolah lain untuk bisa memenuhi ketentuan mengajar 24 jam per minggu (Kompas, 3 Oktober 2008). Hal ini menunjukkan bahwa kinerja guru belum seperti yang diharapkan.

Kajian yang dilakukan Ditjen PMPTK (Baedlowi, 2009) menunjukkan bahwa guru yang telah memperoleh sertifikasi ternyata tidak serta merta menunjukkan peningkatan kinerja. Kajian juga menemukan bahwa motivasi guru untuk segera mengikuti sertifikasi bukanlah semata-mata untuk mengetahui tingkat kompetensi atau ingin menambah kompe-tensi, melainkan yang lebih menonjol adalah motivasi finansial berupa tunjangan profesi.

Temuan lain hasil survei yang dilakukan Persatuan Guru Republik Indonesia (PGRI) mengenai dampak sertifikasi profesi guru terhadap kinerja guru menunjukkan bahwa kinerja guru yang sudah lolos sertifikasi masih belum memuaskan. Motivasi kerja yang tinggi justru ditunjukkan oleh guru-guru di berbagai jenjang pendidikan yang belum lolos sertifikasi, dengan harapan segera mendapat sertifikasi berikut uang tunjangan profesi (Kompas Online, Rabu, 7 Oktober 2009). Hal ini selaras dengan ungkapan Direktur Profesi Ditjen PMPTK (Kedaulatan Rakyat, 24 Mei 2010) yang menyatakan bahwa guru bersertifikasi mengalami penurunan kinerja, sehingga pemerintahakan menunda pemberian tunjangan profesinya.

Kompleksnya permasalahan guru di atas diakibatkan oleh belum tertatanya manajemen/pengelolaan guru secara optimal termasuk dalam hal ini adalah manajemen kinerja. Pembinaan guru selama ini belum secara komprehensif memperhatikan faktor-faktor yang berpengaruh terhadap kinerjanya. Hal ini selaras dengan analisis Djohar (2006:5-6) yang mengemukakan tantangan yang terkait dengan mutu guru berupa tantangan 
pribadi, sosial, kompetensi, profesi, dan keterampilan guru dalam melaksanakan tugasnya. Tantangan tersebut, antara lain (1) sistem pendidikan guru yang tidak menjamin terselenggaranya pendidikan guru yang bermutu; (2) tidak jelasnya manajemen tugas guru yang menjamin pendidikan dapat berjalan dengan baik dan proporsional; (3) standar performance yang menjadi ukuran kinerja guru tidak jelas bagi penyelenggara pendidikan guru yang berakibat pada actual performance guru pada saat melaksanakan tugas kesehariannya tidak jelas ukurannya; dan (4) jaminan kualitas penyelenggaraan pendidikan guru tidak representatif.

Berbagai permasalahan guru di atas makin menunjukkan pentingnya upaya meningkatkan kinerja guru. Guru yang memiliki kinerja rendah tidak saja gagal memenuhi kriteria/standar kinerja namun juga akan memberikan pengaruh jelek kepada orang lain (Jones, Jenkin \& Lord, 2006:2). Guru yang memiliki kinerja rendah dapat berdampak negatif dalam hal (1) reputasi dan citra sekolah di masyarakat, (2) pencapaian kinerja sekolah, (3) kinerja guru lain, (4) kinerja staf pendukung, dan (5) kepemimpinan dan manajerial sekolah. Pembinaan guru akan mencapai hasil maksimal apabila variabel yang secara signifikan mempengaruhi kinerja guru juga ditangani secara serius dan simultan. Oleh karenanya pengkajian tentang hubungan antara kinerja guru dengan berbagai faktor yang berkaitan perlu dilakukan dengan harapan dapat diperoleh gambaran tentang variabel-variabel yang signifikan memberikan kontribusi dan variabel yang paling dominan berpengaruh terhadap kinerja guru. Penelitian ini bermaksud menemukan formula dalam meningkatkan kinerja guru SMK dengan memperhatikan secara komprehensif faktor-faktor yang mempengaruhinya. Hasil penelitian ini diharapkan menjadi masukan berharga bagi perumusan kebijakan dalam pembinaan dan pengelolaan/manajemen kinerja guru secara komprehensif.

Secara umum kinerja dapat dimaknai sebagai hasil atau tingkat keberhasilan seseorang secara keseluruhan selama periode tertentu dalam melaksanakan tugas dibandingkan dengan berbagai kemungkinan seperti standar hasil kerja, target atau sasaran atau kriteria yang telah ditentukan terlebih dahulu dan telah disepakati bersama. Pengertian tentang kinerja yang dikemukakan para ahli (Szilagyi \& Wallace, 1983:360; Stolovic \& Keeps, 1992:4; Cascio, 1992:267; Hersey \& Blanchard, 1996:406), pada 
dasarnya berkaitan dengan output (hasil kerja) dan pencapaian tujuan yang dapat digunakan sebagai bahan pengambilan keputusan pegawai/anggota organisasi. Byars \& Rue (1991:250) mengungkapkan bahwa kinerja selain berkenaan dengan penyelesaian (degree of accomplishment) dari tugas-tugas yang dicapai individu, juga merefleksikan seberapa baik individu itu telah memenuhi persyaratan tugas pekerjaan sehingga kinerja diukur dari aspek hasil. Sedangkan menurut Latham \& Wexley (1981:11), kinerja merupakan beberapa keputusan atau penilaian yang mempengaruhi status pegawai dalam suatu organisasi untuk mengakui referensi, terminasi, promosi, demosi, transfer peningkatan gaji atau penambahan diklat.

Berdasarkan definisi di atas dapat dirumuskan bahwa kinerja (performance) guru adalah hasil yang dicapai oleh guru dalam melaksanakan tugas-tugas yang dibebankan kepadanya yang didasarkan atas kecakapan, pengalaman dan kesungguhan serta waktu dengan output yang dihasilkan tercermin dari kuantitas maupun kualitasnya. Tinggi rendahnya kinerja guru dapat dicermati dari hasil pelaksanaan tugas pokok dan fungsi dalam periode waktu tertentu.

Kinerja individu atau kelompok dalam menjalankan tugas dan fungsinya bukanlah dimensi yang berdiri sendiri, tetapi berhubungan dengan berbagai faktor yang mempengaruhinya. Dari berbagai pendapat (Kierstead, 1998:1-2; Landy and Farr, 1983:8; Byars \& Rue, 1991:250; Muchinsky, 1983; Greenberg \& Baron, 2003:207; Campbell \& Pritchard 1976:64; Robbin, 2006:240-242; Landy \& Farr, 1983:8), secara ringkas dapat dirumuskan bahwa kinerja merupakan fungsi dari kemampuan atau ability (A), motivasi atau motivation (M) dan kesempatan atau opportunity $(\mathrm{O})$ yang dapat pula dimaknai sebagai lingkungan (situasional) atau budaya kerja. Dengan kata lain, kinerja ditentukan oleh faktor-faktor kemampuan, motivasi dan faktor situasional. Hal ini memberi tanda bahwa kinerja tidak hanya dipengaruhi oleh faktor dari dalam diri individu (internal) tetapi juga faktor luar (eksternal). Dalam hal kinerja guru dapat dirumuskan bahwa kinerja guru yang optimal selain didorong oleh kuatnya faktor internal/individual (seperti komitmen, motivasi, dan kemampuan), juga didukung oleh faktor eksternal (situasional) yang memadai (seperti imbalan yang memadai, kepemimpinan yang mendukung dan budaya kerja sekolah yang kondusif). 
Terkait dengan hal tersebut, penelitian ini bertujuan untuk (1) mengetahui gambaran faktor situasional, faktor psikologis, dan kinerja guru SMK di Daerah Istimewa Yogyakarta; (2) menemukan pengaruh faktor situasional dan faktor psikologis terhadap kinerja guru SMK di Daerah Istimewa Yogyakarta; (3) merumuskan hubungan kausal kepemimpinan kepala sekolah, budaya sekolah, imbalan, kemampuan guru, komitmen guru, motivasi kerja guru terhadap kinerja guru SMK di Daerah Istimewa Yogyakarta.

\section{Metode}

Penelitian yang dilakukan merupakan penelitian korelasional, bertujuan untuk merumuskan faktor-faktor dominan yang berpengaruh terhadap kinerja guru SMK. Dalam penelitian ini tidak ada pengendalian atau perlakuan terhadap variable bebas secara langsung karena peristiwa telah terjadi, sehingga penelitian ini termasuk penelitian ex-post facto (Ary, Jacobs \& Razavieh, 1982:282; Gay, 1981:197; Issac, 1981:50).

Populasi penelitian adalah seluruh guru produktif SMK Kelompok Keahlian Teknologi dan Industri, Bidang Keahlian Teknik Mesin di Daerah Istimewa Yogyakarta yang berjumlah 187 orang. Ukuran sampel ditentukan dengan formula Cohen (1977: 440-442) sejumlah 155 orang guru SMK.

Teknik pengumpulan data dalam penelitian ini adalah survei dengan menggunakan alat pengumpul data berupa lembar inventori, lembar pengamatan, dan penilaian diri (self assessment). Untuk mengetahui validitas isi instrumen dilakukan dengan expert judgment atau pertimbangan ahli dalam dua putaran yang diakhiri Focused Group Discussion (FGD) yang melibatkan 24 orang ahli.

Pengujian validitas konstruk menggunakan analisis faktor untuk mengetahui apakah butir-butir instrumen tersebut cocok untuk menaksir unsur-unsur yang terdapat dalam konstruk yang telah ditetapkan (Ary, Jacobs \& Razavieh, 1982:289-291; Coakes \& Steed, 1996:123). Kriteria kelayakan instrumen maupun butir instrumen yang digunakan dalam penelitian ini adalah sebagai berikut.

(1) KMO berada di atas 0,5 dan probabilitas (Sig.) di bawah 0,05. 
(2) Pada tabel anti-images matrices kolom anti-images correlations angka korelasi yang bertanda "a" arah diagonal dari kiri atas ke kanan bawah menunjukkan Measures of Sampling Adequacy (MSA) di atas 0,05.

(3) Pada tabel communalities (kolom extraction), butir instrumen memiliki komunalitas di atas 0,25 .

(4) Pada tabel total variance explained, nilai kumulatif indikator yang membentuk variabel menunjukkan angka lebih besar dari 50. Tidak tercapainya angka 100\% menunjukkan bahwa masih ada beberapa faktor lain yang belum dikembangkan dan mempengaruhi pembentukan komponen yang dijelaskan.

(5) Rotasi faktor (tabel rotated component matrix), butir memiliki muatan faktor di atas 0,32 .

(6) Pergeseran butir menurut indikator penyusun variabel dapat dilihat dalam tabel rotated component matrix.

Butir instrumen yang tidak layak/memenuhi kriteria dalam penelitian ini digugurkan dan tidak diikutsertakan dalam instrumen pengambil data. Dengan demikian, instrumen yang digunakan dalam penelitian ini memenuhi validitas konstruk.

Estimasi reliabilitas dalam penelitian ini menggunakan formula Alpha dari Cronbach (Fernandez (1984:61). Hasil perhitungan menunjukkan bahwa semua instrumen memiliki reliabilitas yang lebih besar dari 0,5 sehingga memadai untuk mengumpulkan data (Thorndike dan Hagen, 1984).

Teknik analisis data dalam penelitian ini meliputi dua analisis yaitu analisis deskriptif dan analisis inferensial (uji hipotesis) dengan terlebih dahulu dilakukan uji persyaratan analisis (normalitas, linieritas, homoskedastisitas, dan multikolinieritas).

\section{Hasil Penelitian dan Pembahasan}

Pengaruh kepemimpinan kepala sekolah, budaya sekolah, imbalan, kemampuan guru, komitmen guru, dan motivasi kerja guru terhadap kinerja guru dapat diketahui dengan menguji hipotesis yakni ada pengaruh signifikan kepemimpinan kepala sekolah $\left(\mathrm{X}_{1}\right)$, budaya sekolah $\left(\mathrm{X}_{2}\right)$, imbalan 
$\left(\mathrm{X}_{3}\right)$, kemampuan guru $\left(\mathrm{X}_{4}\right)$, komitmen guru $\left(\mathrm{X}_{5}\right)$ dan motivasi kerja guru $\left(\mathrm{X}_{6}\right)$ terhadap kinerja guru $(\mathrm{Y})$. Hasil analisis regresi ganda menunjukkan bahwa $\mathrm{F}_{\text {hitung }}(15,497)>\mathrm{F}_{\text {tabel }}(2,16)$ dan $\mathrm{p}<0,05$, maka harga korelasi $(\mathrm{R})=$ 0,621 adalah signifikan pada taraf signifikansi 0,05. Berdasarkan hasil analisis tersebut maka hipotesis tentang adanya pengaruh signifikan kepemimpinan kepala sekolah $\left(\mathrm{X}_{1}\right)$, budaya sekolah $\left(\mathrm{X}_{2}\right)$, imbalan $\left(\mathrm{X}_{3}\right)$, kemampuan guru $\left(\mathrm{X}_{4}\right)$, komitmen guru $\left(\mathrm{X}_{5}\right)$ dan motivasi kerja guru $\left(\mathrm{X}_{6}\right)$ terhadap kinerja guru $(\mathrm{Y})$ dapat diterima. Koefisien determinasi (Adjusted $\left.R^{2}\right)=0,361$ menunjukkan sumbangan enam variabel tersebut sebesar $36,1 \%$.

Model hubungan kausal empiris dengan menghilangkan koefisien jalur di bawah 0,05 (tidak signifikan) ditampilkan pada Gambar 1.

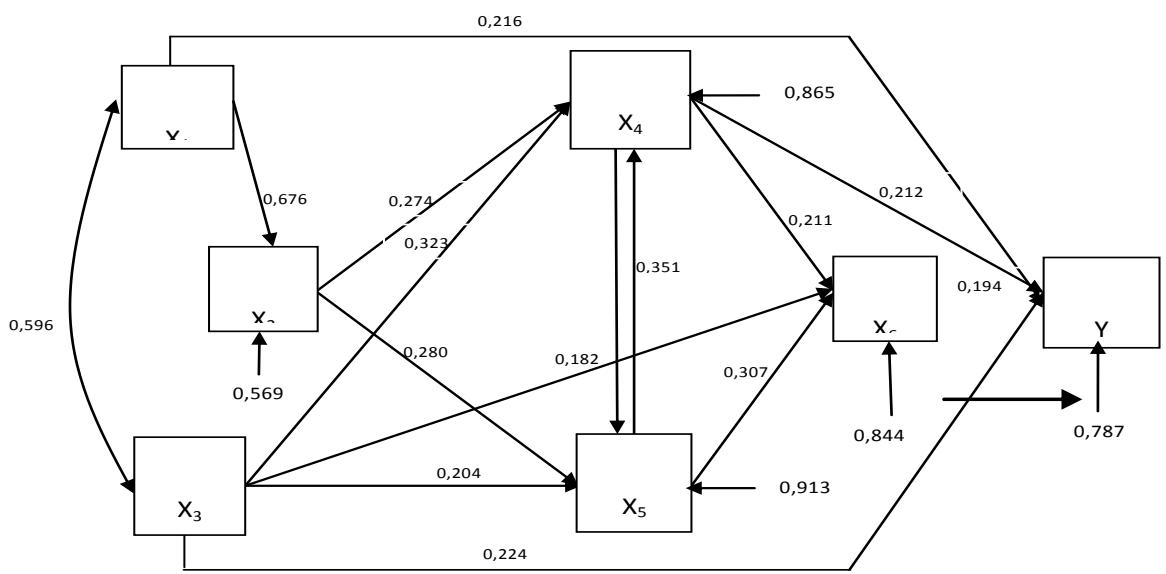

Keterangan:

$\mathrm{X}_{4}$ : Kemampuan Guru

$\mathrm{X}_{1}$ : Kepemimpinan Kepala Sekolah $\mathrm{X}_{5}$ : Komitmen Guru

$\mathrm{X}_{2}:$ Budaya Sekolah

$\mathrm{X}_{3}$ : Imbalan

$\mathrm{X}_{6}$ : Motivasi Kerja Guru

$\mathrm{Y}$ : Kinerja Guru

Gambar 1. Model Hubungan Kausal Empirik

Hasil uji hipotesis menunjukkan bahwa kepemimpinan kepala sekolah, budaya sekolah, imbalan, kemampuan guru, komitmen guru dan motivasi kerja guru memiliki pengaruh signifikan terhadap kinerja guru. 
Sementara itu secara sendiri-sendiri kepemimpinan kepala sekolah, budaya sekolah, imbalan, kemampuan guru dan motivasi kerja guru memiliki pengaruh signifikan terhadap kinerja guru. Hal tersebut menunjukkan bahwa tinggi-rendahnya kinerja guru akan dipengaruhi oleh kepemimpinan kepala sekolah, budaya sekolah, imbalan, kemampuan guru, dan motivasi kerja guru.

Temuan tersebut selaras dengan berbagai rumusan (Kierstead, 1998:1-2; Landy \& Farr, 1983:8; Rivai \& Basri, 2005:33; Byars \& Rue, 1991:250; Greenbergh \& Baron, 2003:207; dan Robbin, 2006:240-242) yang menyatakan bahwa faktor kemampuan dan motivasi (internal) serta faktor lingkungan (eksternal) merupakan faktor yang berpengaruh dan menentukan kinerja termasuk kinerja guru. Interaksi berbagai faktor tersebut akan menentukan kualitas kerja yang ditunjukkan guru dalam pelaksanaan tugasnya.

Kepemimpinan kepala sekolah, baik transformasional maupun transaksional berperan dalam menstimulasi anggota untuk bersama-sama terlibat dalam upaya mewujudkan cita-cita sekolah. Kepemimpinan kepala sekolah yang baik akan mampu menggerakkan anggota sekolah termasuk guru untuk melakukan tindakan sesuai tujuan yang ditetapkan. Jelas bahwa semakin baik kepemimpinan kepala sekolah akan semakin baik pula perilaku yang ditunjukkan guru dan pada akhirnya terwujud dalam hasil pekerjaan atau kinerja. Hal ini selaras dengan temuan penelitian yang dilakukan Husdarta (2005:1); Saefudin (2005:1); Hasanah (2007:1); Salma (2007:1); Nurjanah (2007:1); Atwater \& Yammarino (1996:17-21); Wagimo \& Ancok (2005:122-125); Martono (2007), dan Suarsa (2007:1) yang menunjukkan pengaruh signifikan kepemimpinan baik transaksional maupun transformasional terhadap kinerja guru dengan variasi determinasi.

Budaya sekolah yang baik tercermin dari tingginya kerjasama antarguru dalam menyelesaikan permasalahan-permasalahan profesional sesuai bidang tugasnya, tumbuhnya rasa nyaman diantara guru untuk melakukan tugas sesuai tujuan sekolah, tingginya kolegialitas/saling mendukung diantara guru, dan tumbuhnya rasa pemenuhan keinginan untuk bekerja secara profesional. Suasana kondusif tersebut diharapkan mampu menumbuhkan motivasi guru untuk berprestasi, berani mengambil 
resiko, berafiliasi, kemandirian yang akan menimbulkan harapan yang tinggi terhadap tercapainya tujuan dan pada akhirnya mampu meningkatkan kinerja yang dihasilkan. Pengaruh signifikan budaya sekolah terhadap kinerja guru selaras dengan hasil penelitian yang dilakukan oleh Suarsa (2007:1); Stolp (1994:1); Peterson (1999:2); Hamilton \& Richardson (Colley: 1999:15-16); Kahar (2003); dan Prayitno (2005).

Pengaruh yang tidak signifikan budaya sekolah terhadap kinerja guru perlu dikaji mendalam. Hal ini menunjukkan bahwa budaya sekolah sebagai faktor eksternal belum mampu menciptakan suasana kondusif yang mampu mendorong guru untuk melaksanakan tugas dan menunjukkan kinerja secara optimal.

Imbalan yang baik akan menyangkut kecukupan penghasilan yang diperoleh guru, kepuasan penyelesaian tugas maupun penghargaan yang diterima dari atasan maupun sekolah. Dengan imbalan yang baik, guru memiliki kesempatan yang lebih luas untuk meningkatkan profesionalisme. Imbalan tersebut akan menumbuhkan dorongan yang kuat bagi guru untuk melaksanakan tugas. Kondisi ini akan menumbuhkan keyakinan guru terhadap nilai-nilai yang tumbuh di sekolah, menumbuhkan semangat untuk melakukan yang terbaik demi kemajuan sekolah, serta meningkatkan loyalitas terhadap sekolah dan pada akhirnya mampu meningkatkan kinerja yang ditunjukkkan. Hal ini selaras dengan temuan Aritonang (2005:8-14); Davis (2004:1-8); Glewwe, Ilias, \& Kremer (2003:32-35); Figlio \& Kenny (2003:18-19); McKinney (2000:21-33); Greene \& Forster (2008:3); Hanushek (2006:6-7); McEwan \&Santibanez (2005:21-22) yang menunjukkan pengaruh signifikan imbalan terhadap kinerja guru dengan berbagi ragam determinasi.

Kemampuan guru yang tinggi dalam aspek akademik maupun nonakademik merupakan modal dasar yang kuat bagi guru untuk melaksanakan tugas sesuai dengan tujuan sekolah. Dengan kemampuan yang tinggi, guru akan semakin percaya diri dengan penuh keyakinan untuk melaksanakan tugas-tugas profesionalnya. Dengan demikian semakin tinggi kemampuan guru semakin tinggi pula motivasi guru untuk menunjukkan perilaku sesuai dengan tujuan sekolah dan pada akhirnya mampu meningkatkan kinerja yang ditunjukkannya. Hal ini selaras dengan hasil penelitian Kartana 
(2006:87-96); Husdarta (2005:1); dan Agustina (2002:1); yang menunjukkan pengaruh signifikan kemampuan terhadap kinerja guru.

Tingginya komitmen guru tercermin dalam keyakinan guru terhadap nilai-nilai yang tumbuh di sekolah, tumbuhnya semangat untuk melakukan yang terbaik demi kemajuan sekolah, serta meningkatnya loyalitas terhadap sekolah. Nilai-nilai tersebut memiliki kaitan erat dengan dorongan bagi guru untuk berprestasi, menghadapi resiko, berafiliasi, tumbuhnya harapan pemenuhan kebutuhan yang pada akhirnya mampu meningkatkan kinerja guru. Penelitain yang dilakukan Haryadi (2005:134-251); Varona (1996:811); Shore \& Wayne (1993:778-780); Tsui \& Cheng (1999:249-268); dan Fortmann, et al. (2003:11-13) menunjukkan pengaruh signifikan komitmen terhadap kinerja guru.

Motivasi merupakan faktor pendorong atau penggerak seseorang termasuk guru untuk melakukan tindakan sesuai dengan kebutuhan dan tujuan yang ditetapkan. Untuk memenuhi kebutuhan dan tujuan tersebut, semakin giat guru melaksanakan pekerjaannya dengan baik akan semakin mudah kebutuhan dan tujuan tersebut tercapai. Hal ini menimbulkan keyakinan pentingnya motivasi dalam menentukan kinerja guru. Dalam konteks motivasi kerja, semakin tinggi dorongan guru untuk berprestasi, menyukai tantangan, menunjukkan eksistensi, berafiliasi, mengaktualisasikan potensi yang dimiliki, menunjukkan kemandirian dan harapan, makin tinggi pula kinerja yang ditunjukkan. Hal ini sejalan dengan temuan Haryadi (2005:134-251); Husdarta (2005:1); Salma (2007:1); dan Wagimo \& Ancok (2005:122-125) yang menunjukkan pengaruh dan sumbangan signifikan motivasi kerja terhadap kinerja.

Berdasarkan hasil pengujian hipotesis dapat dirumuskan bahwa peningkatan kinerja guru dapat dilakukan melalui peningkatan kepemimpinan kepala sekolah, budaya sekolah, imbalan, kemampuan guru, komitmen guru dan motivasi kerja guru. Kepemimpinan kepala sekolah dan kemampuan guru memiliki peran dominan dalam menentukan kinerja guru sehingga variabel tersebut perlu mendapatkan perhatian serius dalam upaya meningkatkan kinerja guru di samping budaya sekolah dan imbalan. Perhatian perlu pula diberikan kepada budaya sekolah yang belum menunjukkan peran signifikan terhadap kinerja guru secara langsung. Melalui 
berbagai upaya diharapkan budaya sekolah dapat berkontribusi positif dan mendorong peningkatan kinerja guru dalam berbagai aspek yang melingkupinya.

Hasil analisis jalur menunjukkan bahwa pengaruh langsung kepemimpinan kepala sekolah terhadap kinerja guru signifikan, namun pengaruh tak langsung melalui kemampuan guru, dan motivasi kerja guru tidak signifikan. Secara statistik hal ini dapat dicermati dari berbagai aspek di antaranya adalah kemungkinan adanya korelasi yang relatif tinggi di antara variabel bebas meskipun masih berada di batas bawah terjadinya multikolinieritas. Kemungkinan lain dapat dicermati adalah hadirnya suppresed variable yang mengakibatkan korelasi yang tinggi antara variabel bebas dengan terikat, namun setelah dimasukkan dalam persamaan regresi tidak menunjukkan pengaruh signifikan. Aspek lain yang perlu diperhatikan adalah kualitas instrumen.

Pengaruh tak langsung kepemimpinan terhadap kinerja guru yang tidak signifikan menunjukan bahwa kemampuan guru dan motivasi kerja guru kurang berarti dalam menjelaskan pengaruh kepemimpinan kepala sekolah terhadap kinerja guru. Tingginya kepemimpinan kepala sekolah tidak selalu diikuti dengan tingginya kemampuan dan motivasi kerja guru dalam menentukan kinerja guru.

Pengaruh langsung kepemimpinan kepala sekolah terhadap kinerja guru signifikan, namun pengaruh tak langsung melalui komitmen guru dan motivasi kerja guru tidak signifikan. Hal ini menunjukan bahwa komitmen guru dan motivasi kerja guru kurang berarti dalam menjelaskan pengaruh kepemimpinan kepala sekolah terhadap kinerja guru. Tingginya kepemimpinan kepala sekolah tidak selalu diikuti dengan tingginya komitmen guru dan motivasi kerja guru dalam menentukan kinerja guru.

Pengaruh langsung budaya sekolah terhadap kinerja guru tidak signifikan, dan pengaruh tak langsung melalui kemampuan guru dan motivasi kerja guru tidak signifikan. Hal ini menunjukkan bahwa kemampuan guru dan motivasi kerja guru kurang mempunyai arti dalam menjelaskan pengaruh budaya sekolah terhadap kinerja guru. Pengaruh langsung imbalan terhadap kinerja guru signifikan dan pengaruh tak langsung melalui kemampuan guru dan motivasi kerja guru tidak signifikan. Hal ini me- 
nunjukkan bahwa kemampuan guru dan motivasi kerja guru kurang mempunyai arti dalam menjelaskan pengaruh imbalan terhadap kinerja guru.

Pengaruh langsung kemampuan guru terhadap kinerja guru signifikan dan pengaruh tak langsung melalui motivasi kerja guru signifikan. Hal ini menunjukan bahwa motivasi kerja guru mempunyai arti dalam menjelaskan pengaruh kemampuan guru terhadap kinerja guru. Semakin tinggi kemampuan guru semakin tinggi pula motivasi kerja guru yang pada akhirnya menentukan tingginya kinerja guru. Pengaruh langsung komitmen guru terhadap kinerja guru tidak signifikan dan pengaruh tak langsung melalui motivasi kerja guru signifikan. Hal ini menunjukan bahwa motivasi kerja guru mempunyai arti dalam menjelaskan pengaruh komitmen guru terhadap kinerja guru. Semakin tinggi komitmen guru akan mengakibatkan semakin tinggi motivasi yang pada akhirnya menentukan tingginya kinerja guru.

Secara umum hasil analisis menunjukkan bahwa kinerja guru secara dominan dipengaruhi oleh faktor situasional berupa imbalan dan kepemimpinan kepala sekolah, sedangkan faktor psikologis yang paling berperan adalah kemampuan guru dan motivasi kerja guru. Pengaruh faktor situasional lebih bersifat langsung dan belum memberi dampak optimal bagi peningkatan faktor psikologi suntuk kemudian berpengaruh terhadap peningkatan kinerja guru. Kepemimpinan kepala sekolah memberikan pengaruh langsung terhadap peningkatan kinerja guru, namun tidak memberikan pengaruh optimal bagi peningkatan kemampuan guru, komitmen guru dan motivasi kerja guru yang akhirnya mampu meningkatkan kinerja guru. Budaya sekolah tidak berpengaruh signifikan terhadap peningkatan kinerja guru, namun demikian mampu berperan dalam meningkatkan kemampuan guru yang pada akhirnya meningkatkan motivasikerja guru dan kinerja guru. Imbalan mampu memberikan pengaruh terhadap kinerja guru baik langsung maupun tidak langsung melalui kemampuan guru, komitmen guru maupun motivasi kerja guru. Faktor psikologis berupa kemampuan guru dan motivasi kerja guru memiliki pengaruh signifikan baik secara langsung maupun tidak langsung dalam menentukan peningkatan kinerja guru, sedangkan komitmen tidak memberikan pengaruh langsung terhadap 
kinerja guru, namun berperan dalam meningkatkan motivasi kerja guru untuk kemudian mempengaruhi peningkatan kinerja guru.

Berdasarkan temuan di atas, peningkatan aspek kepemimpinan kepala sekolah, imbalan, dan budaya sekolah perlu dilakukan agar lebih mampu memberi dampak positif terhadap faktor psikologis (kemampuan dan motivasi) yang pada akhirnya mampu mempengaruhi peningkatan kinerja guru. Penguatan komitmen guru perlu dilakukan agar lebih optimal di dalam mendorong motivasi kerja guru untuk menghasilkan kinerja yang optimal.

\section{Simpulan}

Hasil uji hipotesis menunjukkan temuan positif mengenai pengaruh kepemimpinan kepala sekolah, budaya sekolah, imbalan, kemampuan guru, komitmen guru, dan motivasi kerja guru terhadap kinerja guru. Hal ini dapat menjadi petunjuk dalam upaya meningkatkan kinerja guru yaitu dengan meningkatkan kepemimpinan kepala sekolah, budaya sekolah, imbalan, kemampuan guru, komitmen guru, dan motivasi kerja guru.

Hasil analisis jalur menunjukkan peran penting variable kemampuan guru dan motivasi kerja guru dalam menjelaskan pengaruh berbagai faktor situasional (kepemimpinan kepala sekolah, budaya sekolah, imbalan) terhadap kinerja guru. Di samping itu, komitmen guru menunjukkan peran signifikan terhadap peningkatan kinerja guru melalui motivasi kerja guru. Oleh karenanya sangat beralasan pentingnya prioritas pengembangan ketiga faktor psikologis tersebut dalam upaya meningkatkan peran aspek situasional (kepemimpinan kepala sekolah, budaya sekolah, imbalan) dalam meningkatkan kinerja guru.

\section{Daftar Pustaka}

Agustina, Endah. (2002) Pengaruh kompetensi professional dan iklim organisasi terhadap kinerja mengajar guru. Tesis, tidak diterbitkan, Universitas Pendidikan Indonesia, Bandung. 
Aritonang, T. (2005). Kompensasi Kerja, disiplin kerja guru dan kinerja guru SMP Kristen BPK PENABUR. Jakarta: BPK Penabur.

Ary, D., Jacobs, L. C., \& Razavieh, E. (1982). Introduction to research in education. (Terjemahan Arief Furchan). New York: Holt, Rinehart and Winston. (Buku asli diterbiitkan tahun 1981).

Atwater, L.E., \& Yammarino. (1996). "Bases of power in relation to leader behavior: A field investigation", Journal of business and psychologi, 11, 322.

Byars, L.,\& Rue, L.W. (2000). Management (skills and application). Boston: Irwin McGraw Hill.

Campbell, J.P., \& Pritchard, R.D. (1976). Motivation theory in industrial and organizational psychology: Handbook of industrial and organization psychology. Chicago: Rand McNally.

Cascio, W.F. (1998). Applied psychology in human resource management (fifth edition). New Jersey: Prentice Hall.

Coakes, S. J., \& Steed, L. G. (1996). SPSS for Windows: Analysis without anguish. New York: John Wiley \& Sons.

Cohen, J. (1977). Statistical power analysis for the behavioral sciences. New York: Academic Press.

Colley, K. M. (1999). Coming to know a school culture. (Disertasi doktor, the Virginia Polythecnic Institute and State University, Virginia).

Davis. April (2004). Examining teacher performance incentives. Texas: House Research Organization. Focus Report, 78,17.

Depdiknas. (2006). Undang-Undang Republik Indonesia Nomor 14 Tahun 2005 tentang Guru dan Dosen. Jakarta: Biro Hukum dan Organisasi Sekretariat Jenderal Departemen Pendidikan Nasional. 
JurnalPenelitiandanEvaluasiPendidikan

.(2007). Sambutan menteri pendidikan nasional dalam upacara peringatan hari pendidikan nasional tanggal 2 mei 2007. Diambil pada tanggal 3 Mei 2007 dari http://www.depdiknas.go.id/ content.php?content= file detailberita\& $\sigma D=341$.

. (2008a). Peraturan menteri pendidikan nasional nomor 13 tahun 2008 tentang standar kompetensi kepala sekolah/madrasah. Jakarta: Depdiknas.

. (2008b) Peraturan pemerintah Republik Indonesia nomor 74 tabun 2008 tentang guru. Jakarta: Depdiknas

(2009). Peraturan menteri pendidikan nasional nomor 39 tabun 2009 tentang pemenuban beban kerja guru dan pengawas satuan pendidikan. Jakarta: Depdiknas

Djohar. (2006). Guru: pendidikan dan pembinaannya. Yogyakarta: Grafika Indah.

Fernandez, H. J. X. (1984). Testing and measurement. Jakarta: National Education Planning, Evaluation and Curriculum Development.

Figlio, D. N., \& Kenny, L. W. (2007). Individual teacher incentives and student performance. Florida: NCALDER.

Fortmann, et al. (2003). The effects of transformational and transactional leadership on affective organizational commitment. Makalah disampaikan dalam the 24th annual IOOB conference, Akron, OH, Maret 2003.

Gay. (1981). Educational research. London: Charles E. Merril Publishing Co.

Glewwe, P., Ilias, N., \& Kremer. (2003). Teacher incentives. Poverty Action Lab. Paper No. 11. April 2003.

Greenberg, J. \& Baron, R.A. (2003). Behavior in organizartion. Understanding and managing the buman side of work (Eight ed). New Jersey: Prentice Hall International Inc.

166 - JurnalPenelitiandanEvaluasiPendidikanTahun17, Nomor1, 2013 
Greene, J.P. \& Foster, G. (2008). Teacher incentives and merit pay. Lincoln: Centre on Innovation and Improvement.

Hanushek, E. A. (2006). Performance Incentives for Teachers and Administrators. Texax: Texas State Senate. Diambil pada tanggal 2 Januari 2009 dari http:// wmw.senate.state.tx.us/75r/Senate/commit/c525/ handouts06/02272006.c525.hanushek.pdf.

Haryadi. (2005). Faktor-faktor yang mempengaruhi kinerja dosen dan hasil belajar mahasiswa Universitas Jenderal Soedirman Purwokerto. Disertasi tidak diterbitkan, Universitas Pendidikan Indonesia, Bandung.

Hasanah, A (2007). Pengaruh perilaku kepemimpinan kepala sekolah terhadap kinerja guru di SLTPN Kota Bandung. Tesis, tidak diterbitkan, Universitas Pendidikan Indonesia, Bandung. Diambil pada tanggal 18 Oktober 2008 dari www.pages-yourfavorit.com/ ppsupi/index.htm.

Hersey, P., \& Blanchard, K.H. (1996). Management of organizational behavior. New York: Pearson

Husdarta. (2005). Faktor-faktor yang mempengaruhi kinerja guru pendidikan jasmani di sekolah dasar, Disertasi doktor, tidak diterbitkan, Universitas Pendidikan Indonesia, Bandung.

Jones, J., Jenkin, M., \& Lord, S. (2006). Developing effective teacher performance. London: Paul Chapman Publishing.

Kahar, I. K. (2003). Budaya kerja dan sikap inovatif sebagai faktor pendukung kinerja para pustakawan perpustakaan perguruan tinggi di Padang. Tesis, tidak diterbitkan, Universitas Negeri Padang, Padang.

Kartana, Tri Jaka. (2006). "Kontribusi faktor determinan dan upaya peningkatan kinerja guru Teknik Mesin Sekolah Menengah Kejuruan”. Jurnal Pendidikan Teknik Mesin, 6, 2 hal. 87-96. 
JurnalPenelitiandanEvaluasiPendidikan

Kemendiknas ancam tunda tunjangan: Guru bersertifikasi menurun kinerjanya. (24 Mei 2010). Kedaulatan Rakyat, p.28.

Kierstead, J. (1998). Personality and job performance: A research observation. Toronto: Research Directorate Policy, Research and Communications Branch Public Service Commission of Canada.

Kompas (2008). Guru Kesulitan Memenuhi Kuota 24 Jam Mengajar. Kesulitan Peroleh Insentif Kesejahteraan Guru. Kompas. bttp:/ / cetak.kompas.com/ read/ xml/2008/10/03/02162058/guru.kesulita n.memenubi.kuota.24.jam.mengajar

Kompas (2008). Dunia Desakkan Kualitas Guru. Serukan Perbaikan Kesejahteraan dan Kondisi Kerja Guru. (4 Oktober 2008). http:/ / cetak.kompas.com/ read/ xml/2008/10/04/01331841/dunia.desa kkan.kualitas.guru.

Landy, F.J. dan Farr, J.L. (1983). The measurement of work performance: methods, theory and applications. London: Academic Press, Inc.

Latham, G.P.,\& Wexley, K.N. (1981) Increasing productivity through performance appraisal. Michigan Styate University: Addison-Wesley Publishing Company.

Nurjanah, Esti.(2004). Pengaruh kepemimpinan kepala sekolah terhadap kinerja guru. Diambil pada tanggal 18 Oktober 2008 dari bttp:/ / eduplus.or.id/ ?page $=$ Artikelevida $=431$ \&idt $=13$.

Nurlaela, Lutfiah. (2008). Kinerja guru setelah sertifikasi. Makalah disajikan dalam Seminar Internasional Revitalisasi Pendidikan Kejuruan dalam Pengembangan SDM Nasional. Diselenggarakan oleh APTEKINDI di Fakultas Teknik Universitas Negeri Padang.

Martono, Trisno. (2007). Kepemimpinan kepala sekolah, kinerja guru, budaya organisasi sekolah pengarubnya terhadap produktivitas sekolah. Surakart: UNS. 
McEwan, P. J., Santibanez, L. (2005). Teacher incentives and student achievement: Evidence from a Mexican reform. http://emlab.berkeley. edu/users/webfac/chay/e251 s05/mcewan.pdf.

McKinney, P. A. (2000). A study to assess the relationships among student achievement, teacher motivation, and incentive pay. Disertasi tidak diterbitkean, Virginia Polytechnic Institute, Virginia.

Muchinsky, P. (1983). Psychology applied to work: An introduction to industrial and organizational psychology. Illinois: The Dorsey Press.

Peterson, K. (1992). Time use flows from school culture: River of values and traditions can nurture or poison staff development hours. [Versi elektronik] Journal of Staff Development, 20, 2.

Prayitno, Widyo Yudo. (2004). Budaya kerja, kemampuan dan komitmen pegawai negeri sipil di biro kepegawaian secretariat daerah Provinsi Jawa Timur. Tesis tidak diterbitkan, Uniersitas Airlangga, Surabaya.

Rita, V \& Basri, A. F. M. (2005). Performance appraisal. System yang tepat untuk menilai kinerja karyawan dan meningkatkan daya saing perusahaan. Jakarta: Rajagrafindo Perkasa.

Robbin, S. P. (2006). Perilaku organisasi : konsep kontroversi, aplikasi. Edisi Indonesia (Terjemahan oleh Benyamin Molan). Jakarta: PT. Prenhallindo. (Edisi asli diterbitkan tahun 2003 oleh Pearson Education Inc. New Jersey Upper Saddle River).

Salma, Yulia. (2007). Hubungan pengetahuan desain instruksional, motivasi kerja dan gaya kepemimpinan kepala Sekolah Menengah Pertama Negeri di subrayon 9 Kota Bandar Lampung. Tesis, Universitas Negeri Lampung, Lampung.

Saefudin, Ade. (2005). Studi tentang kepemimpinan kepala sekolah dan kinerja mengajar guru terhadap mutu pendidikan di sekolah menengah atas negeri se-kota Bandung. Tesis magister,tidak diterbitkan, 
Universitas Pendidikan Indonesia Bandung.Diambil pada tanggal 18 Oktober 2008 dari http:// digilib.upi.edu.

Sertifikasi guru belum mencapai target: 54\% tak penuhi kualifikasi. (17 Mei 2010). Kedaulatan Rakyat, p. 1.

Shore, L. F. and Wayne, S. J. (2003). Commitment and employee behavior comparison of affective commitment and continuance commitment perceived organizational support. [Versi elektronik]. Journal of Applied Psychology, 78 774-780.

Sidhi, Indra J. (2000). Pendidikan dan peran guru dalam era globalisasi, Majalah Komunika No. 25 / tahun VIII/2000.

Stolovic, H.D., \& Keeps, E.J. (1992). Handbook of human performance technology A comprehensive guide for analysis and solving performance problems in organizations. San Fransdisco: Jerney-Bass Publisher.

Stolp, S. \& Smith, S.C (1994). School culture and climate: The role of the leader. [Electronic version].OSSC Bulletin.

Stolp, S. (1994) Leadership for school culture. Diambil pada tanggal 9 Nopember dari http://www.ed.gov/databases/ERIC_Digests/ ed370198.html.

Suarsa, Suharlan Robby. (2007). Hubungan kepemimpinan kepala sekolah, iklim budaya sekolah, kinerja guru, dan kepuasan belajar dengan hasil belajar siswa. Diambil pada tanggal 27 Juni 2008 dari http://digilib. unila.ac.id/go.php?id=laptunilapp-gdl-s2-2007-robbysubar-626.

Szilagyi, A.D. \& Wallace, J.M. Jr (1983) Organizational behaviour and performance. USA: Scott, Foresman \& Co.

Tsui, K. T., \& Cheng, Y. C. (1999). "School organisational health and teacher commitment: A contingency study with multi-level analysis". [Versi elektronik]. Educational research and evaluation, 5(3), 249-268.

170 - JurnalPenelitiandanEvaluasiPendidikanTahun17, Nomor1, 2013 
Varona, F. (1996). "Relationship between communication satisfaction and organizational commitment in three Guatemalan organizations." [Versi elektronik]. The journal of business communication, 33, 2: 111-140.

Wagimo \& Ancok, Djamaludin. (2005). "Hubungan kepemimpinan transformasional dan transaksional dengan motivasi bawahan di militer". Jurnal Psikologi, 32.

Zamroni. (2007). Kualifikasi dan sertifikasi guru SMK. Makalab disajikan dalam Seminar Nasional Kebijakan Pengembangan SMK dan Sertifikasi Guru SMK. Fakultas Teknik UNY.

- (2008). Pendidikan guru di masa depan. Makalah disajikan dalam Konvensi Nasional Pendidikan Indonesia VI. Universitas Pendidikan Ganesha, 17-19 Nopember 2008

(2009). Kebijakan peningkatan mutu sekolah di Indonesia. Makalah disajikan dalam Seminar Nasional dalam Rangka Dies Natalis Ke45 Universitas Negeri Yogyakarta. Auditorium Universitas Negeri Yogyakarta 25 April 2009. 